\title{
COMPARISON STUDY OF STAINLESS STEEL CYCLIC VOLTAMMOGRAMS IN VARIOUS NATURAL MEDIA ADDITION: PRODUCT AND VOLTAGE EFFICIENCY
}

\author{
ISANA SUPIAH YOSEPHINE LOUISE * ENDANG WIDJAJANTI LAKSONO, \\ DEWI YUANITA LESTARI ${ }^{1}$
}

Chemical Education Department, Mathematics and Science Faculty, Yogyakarta State University, Yogyakarta, Indonesia

*Corresponding author: isana_supiah@uny.ac.id

(Received: $4^{\text {th }}$ December 2018; Accepted: $4^{\text {th }}$ July 2019; Published on-line:2 ${ }^{\text {nd }}$ December 2019)

\begin{abstract}
The cyclic voltammogram is widely used to analyse the electrolysis process. The use of various media, namely rambutan seed flour (Nephelium lappaceum), mango seed flour (Mangifera indica), breadfruit leaf powder (Artocarpus altilis), peria extract (Momordi charantia) and aloe vera extract (Aloe vera), in this study is to deliberately mimic the occurrence of those media in wastewater produced by several industries. The electrolysis analysis on the presence of several media would minimize the preparation steps on wastewater utilization for generating hydrogen as renewable energy. The research looks at the potential of wastewater as the raw material for the electrolysis process. In this research, stainless steel cyclic voltammograms were studied on water electrolysis. The electrolysis was done in base solution and adding various media, such as rambutan seed flour (Nephelium lappaceum), mango seed flour (Mangifera indica), breadfruit leaf powder (Artocarpus altilis), peria extract (Momordi charantia) and aloe vera extract (Aloe vera) in various concentrations, 0 - 10 g per litter of water. By reviewing the activity of a stainless steel electrode to decompose water molecules, the media generally caused the occurrence of covering by relatively large molecules around the electrode surface, resulting in decreased activity of the stainless steel electrodes. The optimum condition occurred with the addition of breadfruit leaf powder in all treatments with similar electrode activity as much as 1.68 . The result could be implemented in a wastewater electrolysis processes containing the media to generate hydrogen gas.
\end{abstract}

ABSTRAK: Voltammogram berkitar banyak digunakan bagi menganalisis proses elektrolisis. Dalam kajian ini pelbagai jenis media telah sengaja digunakan seperti tepung biji rambutan (Nephelium lappaceum), tepung biji mangga (Mangifera indica), serbuk daun sukun (Artocarpus altilis), ekstrak peria (Momordi charantia) dan ekstrak lidah buaya (Aloe vera), bagi memimik terjadinya media-media tersebut dalam sisa air buangan yang terhasil daripada beberapa industri. Analisis elektrolisis pada pelbagai media dapat mengurangkan langkahlangkah persiapan pada penggunaan sisa air bagi menghasilkan hidrogen sebagai tenaga boleh baharu. Penilitian kajian ini bertumpu pada potensi sisa air sebagai bahan kasar bagi proses elektrolisis. Kajian ini adalah tentang elektrolisis air voltammogram berkitar pada keluli tahan karat. Proses elektrolisis telah dilakukan pada larutan dasar dan dengan menambah pelbagai media, seperti tepung biji rambutan (Nephelium lappaceum), tepung biji mangga (Mangifera indica), serbuk daun sukun (Artocarpus altilis), ekstrak petola (Momordi charantia) dan ekstrak lidah buaya (Aloe vera) dalam pelbagai kepekatan, 0 - 10 gram pada setiap liter air. Penurunan aktiviti elektrod keluli tahan karat telah disebabkan oleh aktiviti elektrod keluli tahan karat yang mengurai molekul air dan diliputi molekul-molekul besar pada permukaan 
elektrod. Keadaan optimum telah berlaku dengan penambahan serbuk daun sukun pada semua rawatan dengan aktiviti elektrod serupa sebanyak 1.68. Dapatan kajian dapat digunakan dalam proses elektrolisis sisa air yang mengandungi media bagi menghasilkan gas hidrogen.

KEYWORDS: voltammogram; stainless steel; media; electrode activity; efficiency

\section{INTRODUCTION}

The voltammetry method is favourable for synthesis, analysis, and characterization or application, namely linear and cyclic voltammetry. In cyclic voltammetry, the same potential was applied on continuous time measurement for the electric current recording [1-5]. Furthermore, an electric current is plotted against a potential (Voltammogram) which can be used as a basis for analysing samples. For the same sample measured under similar conditions, it will have a similar voltammogram. Otherwise, when the modified state is applied, it will give a different voltammogram. The electrolysis of water will provide a typical cyclic voltammogram with differences occurring for electrodes and media changes. Hence, it could be used to study the efficiency of the electrolysis process.

Water molecules can be decomposed to hydrogen and oxygen gases by electrolysis. The electrolysis process depends on the type of electrolyte, the type of electrode, current, and time used [6-10]. Hydrogen is a well-known renewable energy source with its environmentally friendly property. Hydrogen gas production by electrolysis of water has relatively lowefficiency [11]. Therefore, it is necessary to strive for a condition of electrolysis of water with high efficiency in hydrogen gas production and voltage efficiency. To produce safe, environmentally friendly, and cheap hydrogen it needs an effort to meet energy demand, given the increasing rarity of fossil fuels and their non-renewability.

One of the methods to increase efficiency is through modification of the electrodes. The preparation, characterization, and application of stainless steel electro-catalyst electrodes for producing hydrogen gas had been reported by Isana et al. [12]. The voltammogram pattern of the stainless steel/Fe-Co-Ni electrolysis in base solution had been analysed by [13] and the reaction of hydrogen evolution in the stainless steel/Fe-Co-Ni electrode [14] showed that the ternary electrode has relatively better catalytic activity than binary and single electrodes. The reaction of hydrogen evolution in $\mathrm{Fe}-\mathrm{Co} / \mathrm{s}, \mathrm{Fe}-\mathrm{Ni} / \mathrm{s}$ and $\mathrm{Co}-\mathrm{Ni} / \mathrm{s}$ electrodes [15] showed that stainless steel coated electrodes with binary metals have relatively better catalytic activity than stainless steel electrode. Meanwhile, Islam [16] evaluated the surfaces of Fe-Ni films on various coating bath media and concluded the morphology that is characterized by a coarse-grained and non-smooth surfaces with the presence of micro-cracks on it is superior. Other studies by Hairin et al. [17] and Salim [18] showed that high surface area is produced from the coating using the electrodeposition method.

Another method to increase efficiency is conducted on the batch solution manipulation of water electrolysis. The temperature thermogram against the time of electrolysis of various brands of salt solution using carbon electrodes showed the diversity of thermograms, which differed with each brand that had been studied by Isana [19]. Another study on well water from various places with stainless steel electrodes indicated that each well water has different electrolysis behaviour [20]. Furthermore, the splitting of water molecules in a cornstarch medium had been reported, as well as in the medium of mocaf [21], in the Ipomoea batatas L flour medium [22], in dahlia bulbs flour [23, 24], in the bitter melon medium [25], and in mango 
seed flour [26] showing that there was covering at the surface of the electrode by the flour. Both the production of hydrogen and catalytic activity were relatively dependent on the media. The modification of batch solution can be beneficial on either improving the quality of water electrolysis or utilizing the wastewater of several industries containing several media.

To study the effect of media addition in the water electrolysis process, research was carried out on the electrolysis of water in base solutions by using stainless steel electrodes in various media. The media used in this research were rambutan seed flour (Nephelium lappaceum), mango seed flour (Mangifera indica), breadfruit leaves powder (Artocarpus altilis), peria extract (Momordi charantia) and aloe vera extract (Aloe vera). The major chemical compositions in the media from various studies are described in Table 1 and illustrated in Fig. 1. The problem formulation is (1) how does the activity of the stainless steel electrode affect the process of decomposition of water in various media based on the cyclic voltammogram? (2) How does media concentration affect the decomposition of a water molecule? (3) What is the value of the decomposing water molecule to produce hydrogen and oxygen gases in various media at the optimum condition?

Table 1: Major composition of media in water electrolysis using stainless steel

\begin{tabular}{cccccc}
\hline Media & Carbohydrate & $\begin{array}{c}\text { Fatty } \\
\text { acids }\end{array}$ & $\begin{array}{c}\text { Crude } \\
\text { protein }\end{array}$ & Amylose & Reference \\
\hline Rambutan Seed Flour & $87.04 \%$ & - & $10.07 \%$ & $32.14 \%$ & {$[27]$} \\
Mango Seed Flour & $64.23 \%$ & $12.00 \%$ & $4.95 \%$ & - & {$[28]$} \\
Breadfruit leaves powder & $50.00 \%$ & - & $22.45 \%$ & - & {$[29]$} \\
Peria extract & - & - & $18.02 \%$ & - & {$[30]$} \\
Aloe vera extract & $61.68 \%$ & - & $11.21 \%$ & - & {$[31]$} \\
\hline
\end{tabular}
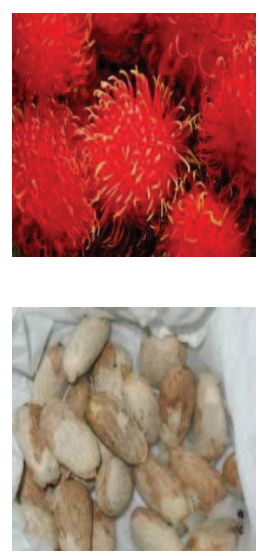

(a)
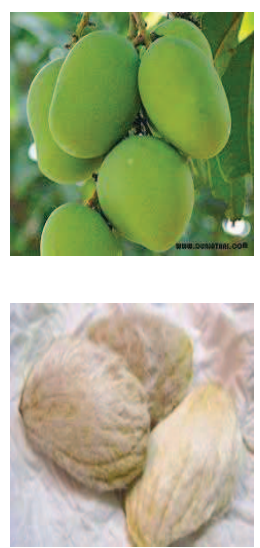

(b)

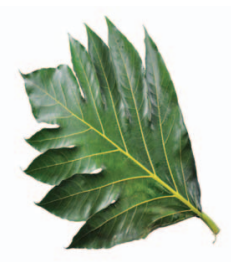

(c)

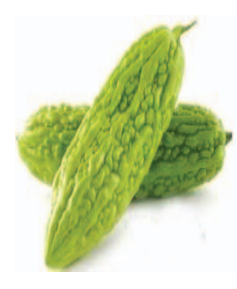

(d)

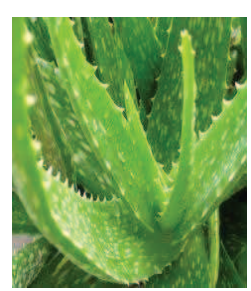

(e)

Fig. 1: (a) Rambutan and seed, (b) mango and seed, (c) breadfruit leave, (d) peria and (e) Aloe vera.

\section{MATERIALS AND METHODOLOGY}

The equipment used here included glassware for preparation, an electrolysis tube, and a eDAQ EChem voltammeter. The materials used were nitric acid, acetone, and $\mathrm{NaHCO}_{3}$ (Merck). Other materials such as stainless steel grades S-430 (thickness $1.2 \mathrm{~mm}$, width $3 \mathrm{~mm}$, 
and length $110 \mathrm{~mm}$ ), platinum electrodes, and $\mathrm{Ag} / \mathrm{AgCl}$ electrodes were equipped as part of the electrolysis apparatus. The solvents, such as distilled water and aquabides, were produced locally in laboratory, while the media of rambutan seed flour, mango flour, breadfruit powder, peria extract, and Aloe vera extract were prepared and extracted from the local market. Several processes such as rinsing, drying, size reduction, and 100-mesh screening were used in the flour production of the media. Meanwhile, aloe vera extract was obtained by crushing the raw material using a blender followed by a filtration process.
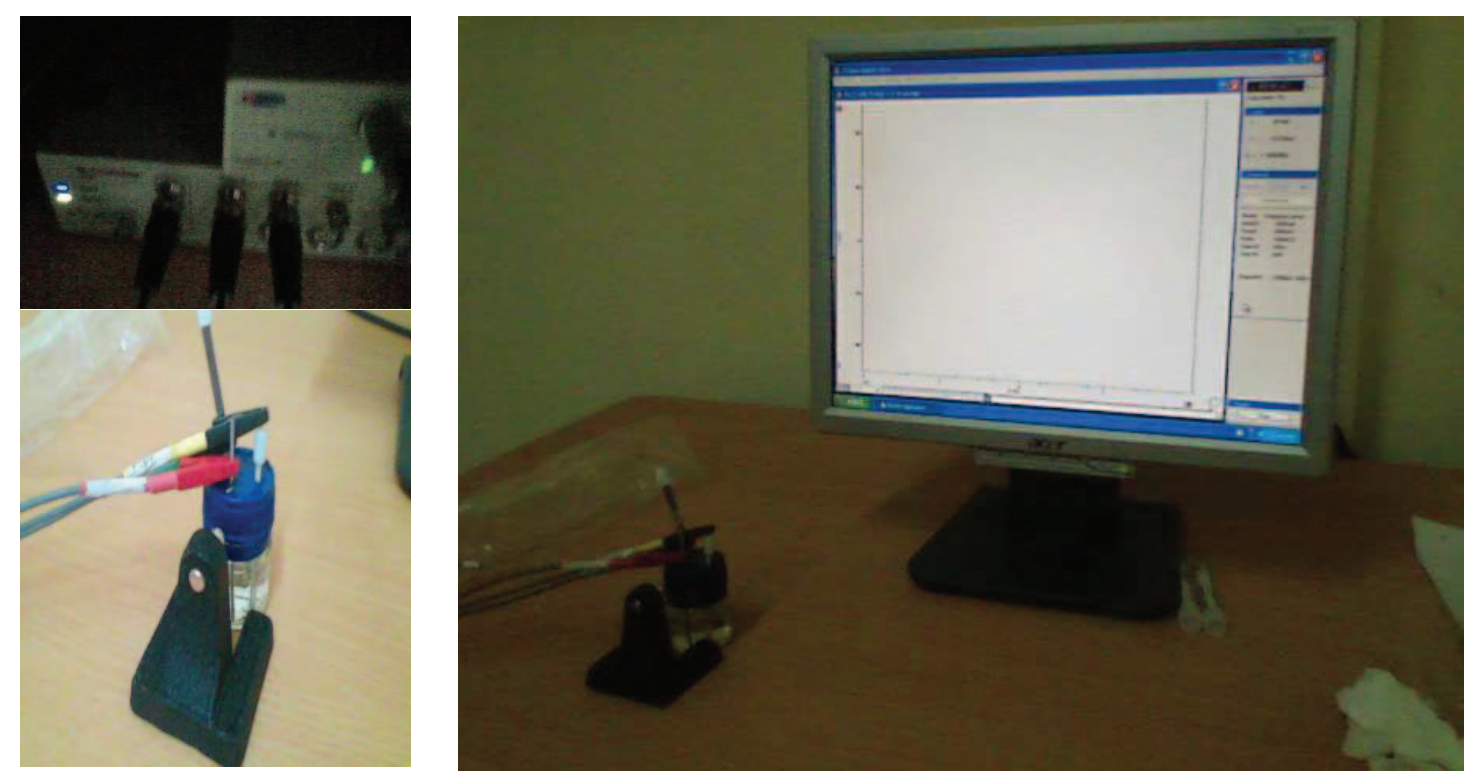

Fig. 2: eDAQ EChem voltammeter equipment in this study.

$\mathrm{NaHCO}_{3}(5 \mathrm{~g})$ was poured into one litre of water to make a base solution of mother liquor. Mother solution was added with each media with various concentrations under constant stirring for 1 hour. The concentration of the media varied from 0 to $10 \mathrm{~g}$ per 1 liter of water. Electrolysis of water was carried out by using stainless steel electrodes and various media. Meanwhile, the eDAQ EChem voltammeter (Fig. 2) was used to analyse the voltammetry during the electrolysis of water using multiple media. Furthermore, cyclic voltammetry was conducted twice for each sample to ensure data reliability. The eDAQ EChem have recorded the value of anodic-cathodic peak current and anodic-cathodic peak potential of the cyclic voltammogram data file experiment, which was further analysed to gain production efficiency and voltage efficiency. Production efficiency was calculated based on a comparison of the cathodic current peak with or without media, as shown in Eq. 1. Meanwhile, voltage efficiency was compared; observed as the voltage at the cathodic peak condition, for every treatment and the treatment without media as shown in Eq. 2. Furthermore, the electrolysis activity is expressed in Eq. 3 as comparing product efficiency and voltage efficiency.

$$
\begin{array}{r}
\text { Product Efficiency }=\frac{I_{\text {with media }}}{I_{\text {without media }}} \times 100 \% \\
\text { Voltage efficiency }=\frac{\text { Operating voltage }}{\text { Thermodynami voltage }} \\
\text { Activity of electrolysis }=\frac{\text { Product efficiency }}{\text { Voltage Ef ficiency }}
\end{array}
$$


where thermodynamic voltage is $1.229 \mathrm{~V}$ at standard temperature and pressure.

\section{RESULTS AND DISCUSSION}

The stainless steel voltammogram in various media can be seen in Fig. 3. Based on the stainless steel cyclic voltammogram, the cathodic current peak and potential for each system of mass of media versus the efficiency of products are presented in Fig. 4 and voltage efficiency in Fig. 5 in various media such as rambutan seed flour, mango seed flour, breadfruit leaves powder, peria extract, and Aloe vera extract. The efficiency of hydrogen product and the voltage efficiency in various media from the cyclic voltammogram are summarized in Table 2. Meanwhile, product efficiency and voltage efficiency also were drawn in Figs. 4 and 5 to compare influences with each other. Furthermore, the activity of electrolysis was shown in Table 3 with the comparison of product efficiency and voltage efficiency in various media. From voltage efficiency, we can calculate the product efficiency using a comparison of voltage efficiency with or without media in every treatment.

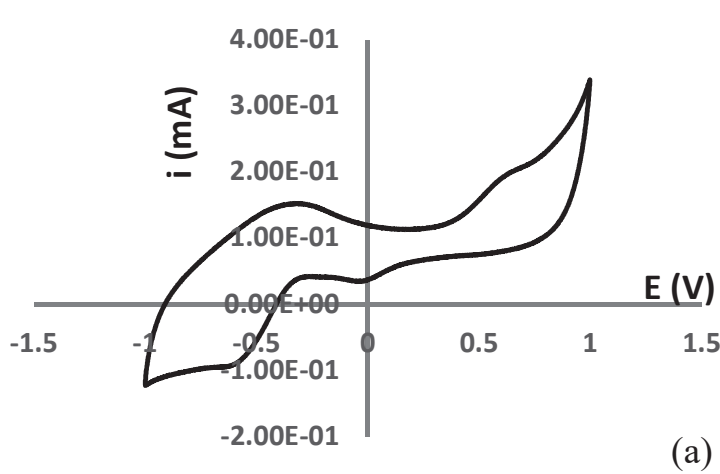

(a)

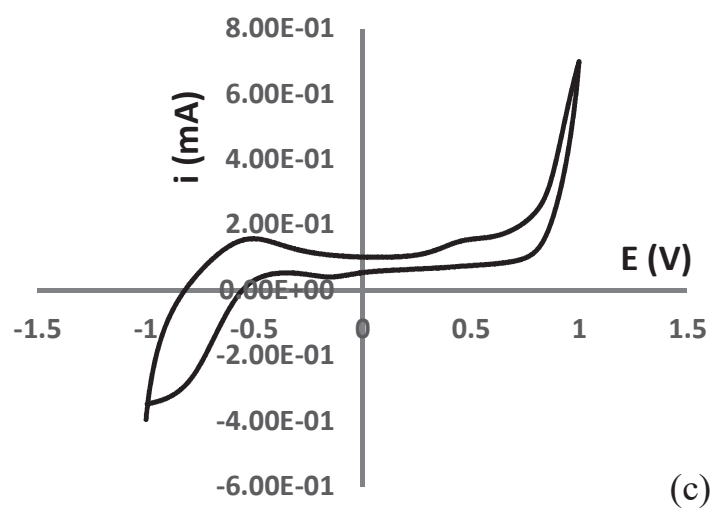

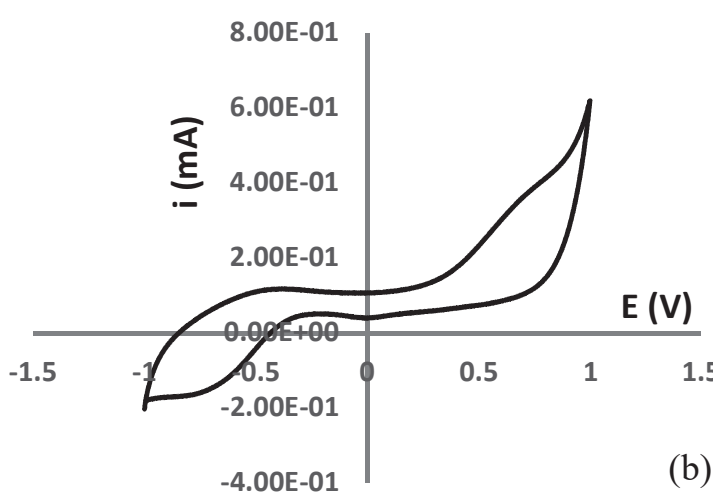

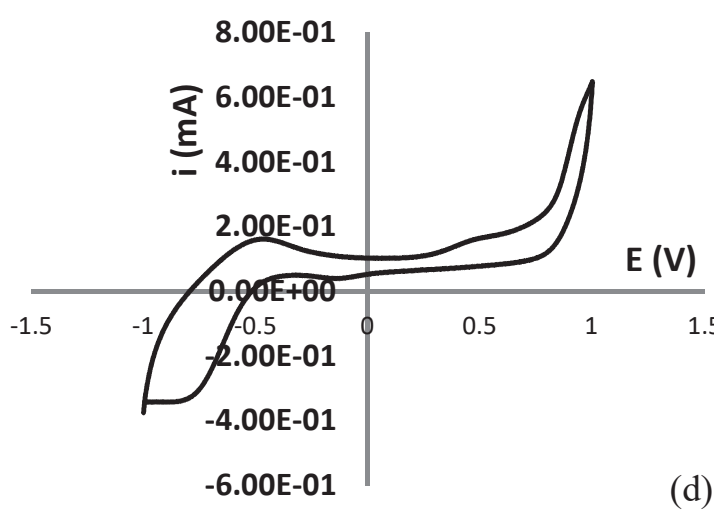



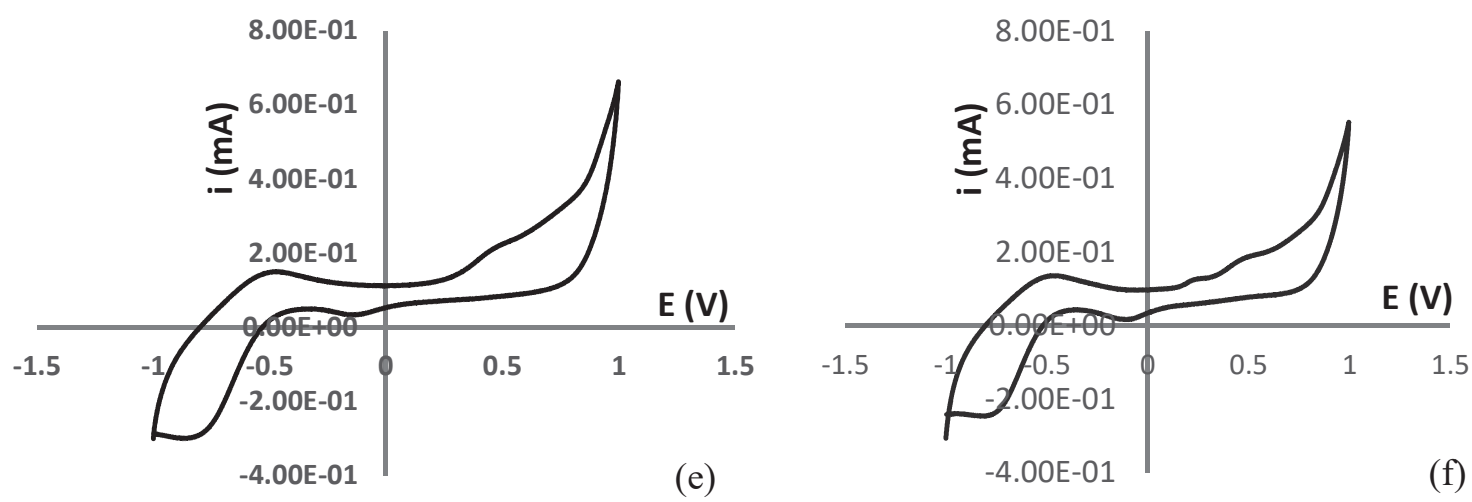

Fig. 3: Cyclic Voltammogram of stainless steel in various media: (a) rambutan seed flour, (b) mango seed flour, (c) breadfruit leaves powder, (d) peria extract, (e) Aloe vera extract, and (f) without media.

Tabel 2: The efficiency of hydrogen product and voltage efficiency in various media

\begin{tabular}{cccccccccccc}
\hline \multirow{2}{*}{ No. System } & \multicolumn{4}{c}{ Product efficiency (\%) } & \multicolumn{5}{c}{ Voltage efficiency (\%) } \\
\cline { 2 - 11 } & & RSF & MSF & BLP & PE & AVE & RSF & MSF & BLP & PE & AVE \\
\hline 1 & $0 \mathrm{~g}$ & 100.0 & 100.0 & 100.0 & 100.0 & 100.0 & 67.4 & 59.2 & 59.6 & 59.3 & 59.8 \\
2 & $1 \mathrm{~g}$ & 74.3 & 46.6 & 97.4 & 61.6 & 62.3 & 55.2 & 48.7 & 58.0 & 58.6 & 60.0 \\
3 & $2 \mathrm{~g}$ & 69.7 & 34.8 & 96.3 & 38.1 & 58.3 & 53.5 & 44.7 & 57.4 & 57.7 & 59.1 \\
4 & $3 \mathrm{~g}$ & 49.6 & 35.5 & 100.8 & 53.2 & 51.0 & 54.4 & 43.8 & 60.0 & 58.7 & 59.7 \\
5 & $4 \mathrm{~g}$ & 59.8 & 30.8 & 102.2 & 56.5 & 48.4 & 53.5 & 43.9 & 60.9 & 58.7 & 59.5 \\
6 & $5 \mathrm{~g}$ & 72.7 & 36.1 & 98.9 & 55.7 & 40.2 & 53.5 & 47.0 & 58.9 & 56.1 & 59.6 \\
7 & $6 \mathrm{~g}$ & 67.4 & 34.0 & 95.0 & 55.1 & 36.2 & 55.2 & 46.6 & 56.6 & 56.6 & 59.2 \\
8 & $7 \mathrm{~g}$ & 68.7 & 26.7 & 98.1 & 21.3 & 36.0 & 54.4 & 50.7 & 58.4 & 56.1 & 59.2 \\
9 & $8 \mathrm{~g}$ & 53.4 & 30.4 & 95.6 & 19.5 & 22.8 & 53.5 & 47.2 & 57.0 & 54.4 & 59.1 \\
10 & $9 \mathrm{~g}$ & 40.7 & 36.7 & 99.5 & 48.5 & 25.5 & 54.4 & 46.3 & 59.2 & 53.6 & 59.2 \\
11 & $10 \mathrm{~g}$ & 40.6 & 35.6 & 96.5 & 35.8 & 27.7 & 53.5 & 47.4 & 57.4 & 49.9 & 59.3 \\
\hline
\end{tabular}

RSF: rambutan eed flour, MSF: mango seed flour, BLP: breadfruit leaves powder, PE: peria extract, and AVE: Aloe vera extract

Cyclic stainless steel voltammograms in various media can be used to study the activity of the stainless steel electrode on decomposition of water molecules to form hydrogen and oxygen gases. The comparison between product gained, and the voltage efficiency is the best method to represent the activity of the stainless steel electrode on decomposition of water molecules to form hydrogen and oxygen gases. Randles-Sevcik's equation describes that the peak current for a reversible system is affected by electron stoichiometry $(\mathrm{n})$, electrode area $\left(\mathrm{A}, \mathrm{cm}^{2}\right)$, diffusion coefficient $\left(\mathrm{D}, \mathrm{cm}^{2} / \mathrm{s}\right)$, concentration $\left(\mathrm{mol} / \mathrm{cm}^{3}\right)$, and scan rate $(\mathrm{v}, \mathrm{V} / \mathrm{s})$ as shown at Eq. 5. Thus, the concentration of the product is affecting the peak current of cyclic voltammetry. Voltage efficiency is the value of energy used to produce hydrogen and oxygen gas compared to the initial condition without any addition of the media.

$$
I_{p}=\left(2.69 \times 10^{5}\right) n^{3 / 2} A D^{1 / 2} C v^{1 / 2}
$$




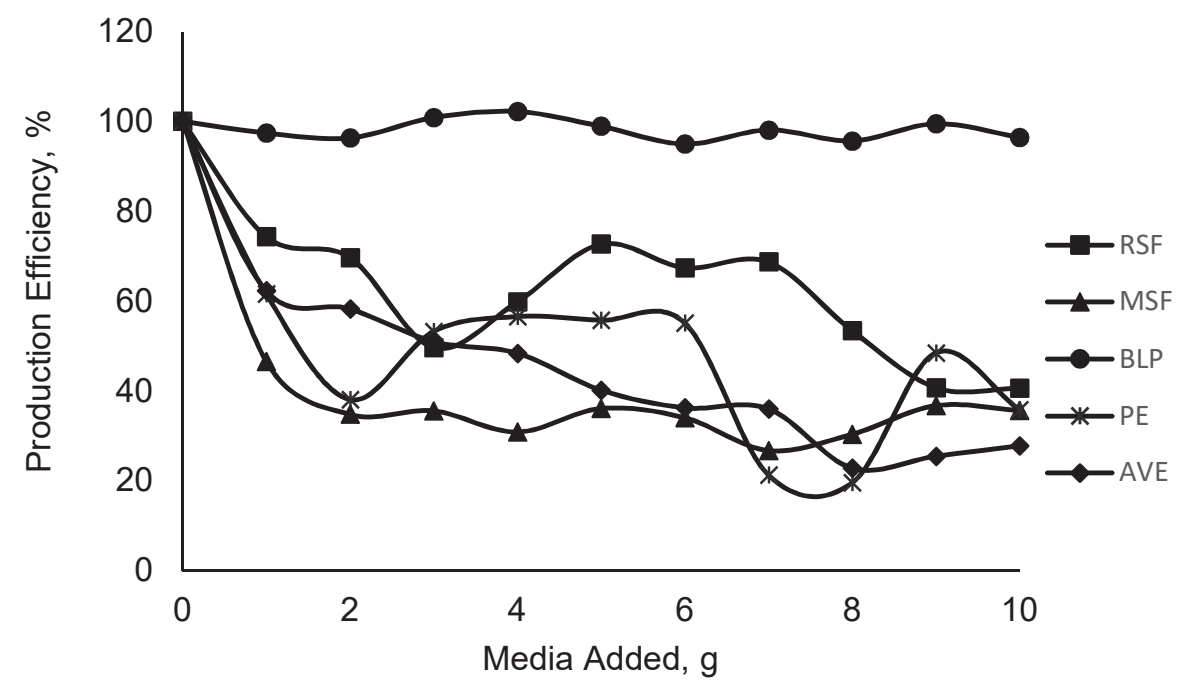

Fig. 4: The efficiency of hydrogen product of various media.

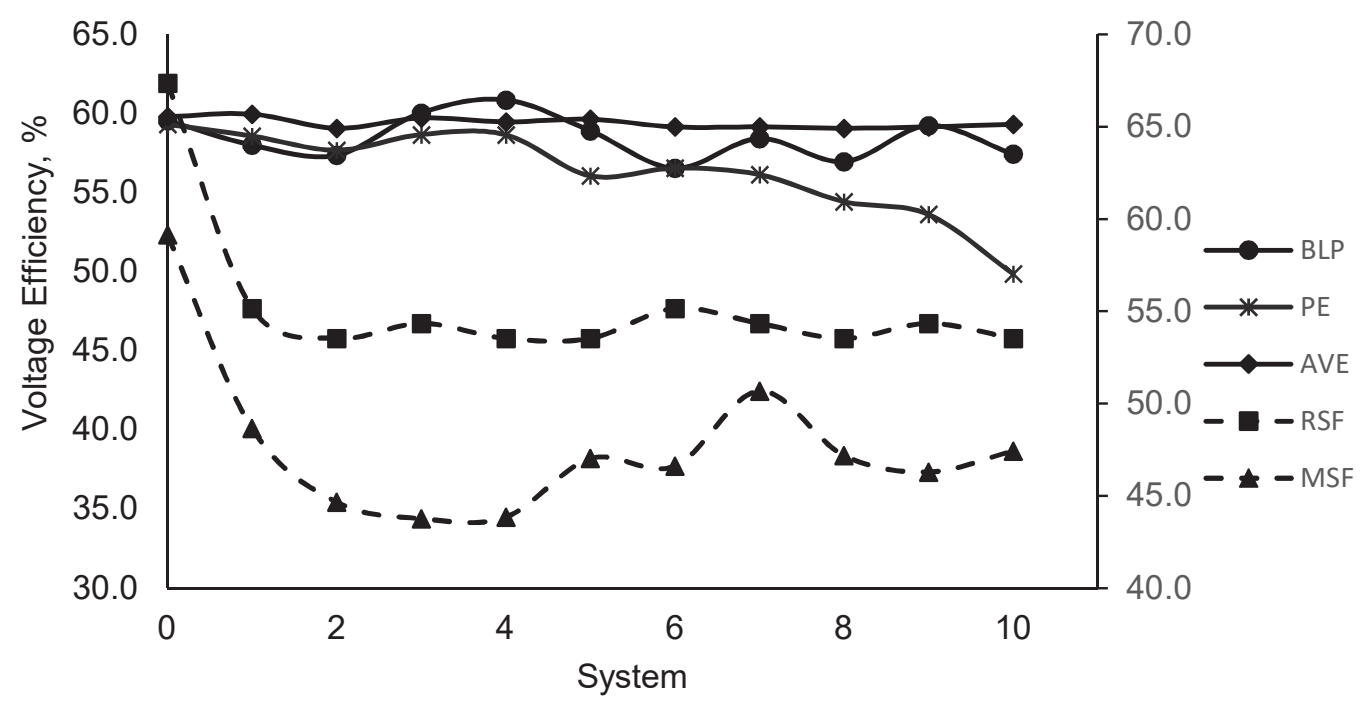

Fig. 5: The voltage efficiency of various media, solid and dotted line indicated major and minor y-axis respectively.

Regarding voltage efficiency, the addition of rambutan seed flour and mango seed flour showed decreasing result. Meanwhile, the other media did not significantly impact voltage efficiency. The result of the hydrogen product yield, ranked from relatively high efficiency to relatively small efficiency, is as follows: breadfruit leaves powder, rambutan seed flour, peria extract, Aloe vera extract, and mango seed flour. When viewed from energy consumption, illustrated with voltage efficiency, the sequence becomes: mango seed flour, rambutan seed flour, peria extract, breadfruit leaf powder, and Aloe vera extract. The most unfavourable 
medium to decompose water molecules into hydrogen and oxygen gases was the Aloe vera extract.

From Table 3, it can be concluded that the bigger the value, the better the activity of the stainless steel electrode is. The calculation using least significant difference was conducted to analyse the significance of the activity of electrolysis value. In general, the media caused the covering surface of the electrode because of its relatively large molecules, resulting in decreased activity of the electrode, as presented in Fig. 6 (b). From Eq. 4, it can be shown that the presence of media can disturb the diffusivity $\left(\mathrm{D}, \mathrm{cm}^{2} / \mathrm{s}\right)$ because the media are covering the electrode. Interestingly, the addition of Breadfruit Leaves Powder gave an unusual trend, as shown in Fig. 6 (a). Those graph tendencies are strongly believed to be the result of the polymer structure in the media that had not covered the electrode. The polymer occurrence in every media affects the interaction between the surface of the electrode and the polymer itself influences the electrode activity.

Tabel 3: Activity of electrolysis in various media

\begin{tabular}{ccccccc}
\hline \multirow{2}{*}{ No } & \multirow{2}{*}{ System } & \multicolumn{5}{c}{ Activity of Electrolysis } \\
\cline { 3 - 7 } & & RSF & MSF & BLP & PE & AVE \\
\hline 1 & $0 \mathrm{~g}$ & $1.49^{\mathrm{b}}$ & $1.70^{\mathrm{a}}$ & $1.68^{\mathrm{a}}$ & $1.69^{\mathrm{a}}$ & $1.68^{\mathrm{a}}$ \\
2 & $1 \mathrm{~g}$ & $1.35^{\mathrm{b}}$ & $0.96^{\mathrm{b}}$ & $1.68^{\mathrm{a}}$ & $1.06^{\mathrm{b}}$ & $1.04^{\mathrm{b}}$ \\
3 & $2 \mathrm{~g}$ & $1.31^{\mathrm{b}}$ & $0.78^{\mathrm{c}}$ & $1.68^{\mathrm{a}}$ & $0.66^{\mathrm{c}}$ & $0.99^{\mathrm{b}}$ \\
4 & $3 \mathrm{~g}$ & $0.92^{\mathrm{c}}$ & $0.82^{\mathrm{c}}$ & $1.68^{\mathrm{a}}$ & $0.91^{\mathrm{c}}$ & $0.86^{\mathrm{c}}$ \\
5 & $4 \mathrm{~g}$ & $1.12^{\mathrm{b}}$ & $0.71^{\mathrm{c}}$ & $1.68^{\mathrm{a}}$ & $0.97^{\mathrm{b}}$ & $0.82^{\mathrm{c}}$ \\
6 & $5 \mathrm{~g}$ & $1.36^{\mathrm{b}}$ & $0.77^{\mathrm{c}}$ & $1.68^{\mathrm{a}}$ & $1.00^{\mathrm{b}}$ & $0.68^{\mathrm{c}}$ \\
7 & $6 \mathrm{~g}$ & $1.23^{\mathrm{b}}$ & $0.73^{\mathrm{c}}$ & $1.68^{\mathrm{a}}$ & $0.98^{\mathrm{b}}$ & $0.62^{\mathrm{c}}$ \\
8 & $7 \mathrm{~g}$ & $1.27^{\mathrm{b}}$ & $0.53^{\mathrm{c}}$ & $1.68^{\mathrm{a}}$ & $0.38^{\mathrm{c}}$ & $0.61^{\mathrm{c}}$ \\
9 & $8 \mathrm{~g}$ & $1.00^{\mathrm{b}}$ & $0.65^{\mathrm{c}}$ & $1.68^{\mathrm{a}}$ & $0.36^{\mathrm{c}}$ & $0.39^{\mathrm{c}}$ \\
10 & $9 \mathrm{~g}$ & $0.75^{\mathrm{c}}$ & $0.80^{\mathrm{c}}$ & $1.68^{\mathrm{a}}$ & $0.91^{\mathrm{c}}$ & $0.44^{\mathrm{c}}$ \\
11 & $10 \mathrm{~g}$ & $0.76^{\mathrm{c}}$ & $0.76^{\mathrm{c}}$ & $1.68^{\mathrm{a}}$ & $0.72^{\mathrm{c}}$ & $0.47^{\mathrm{c}}$ \\
\hline
\end{tabular}

RSF: rambutan seed flour, MSF: mango seed flour, BLP: breadfruit leaves powder, PE: peria extract, and AVE: Aloe vera extract $\mathrm{a}, \mathrm{b}$, and c show significance group.
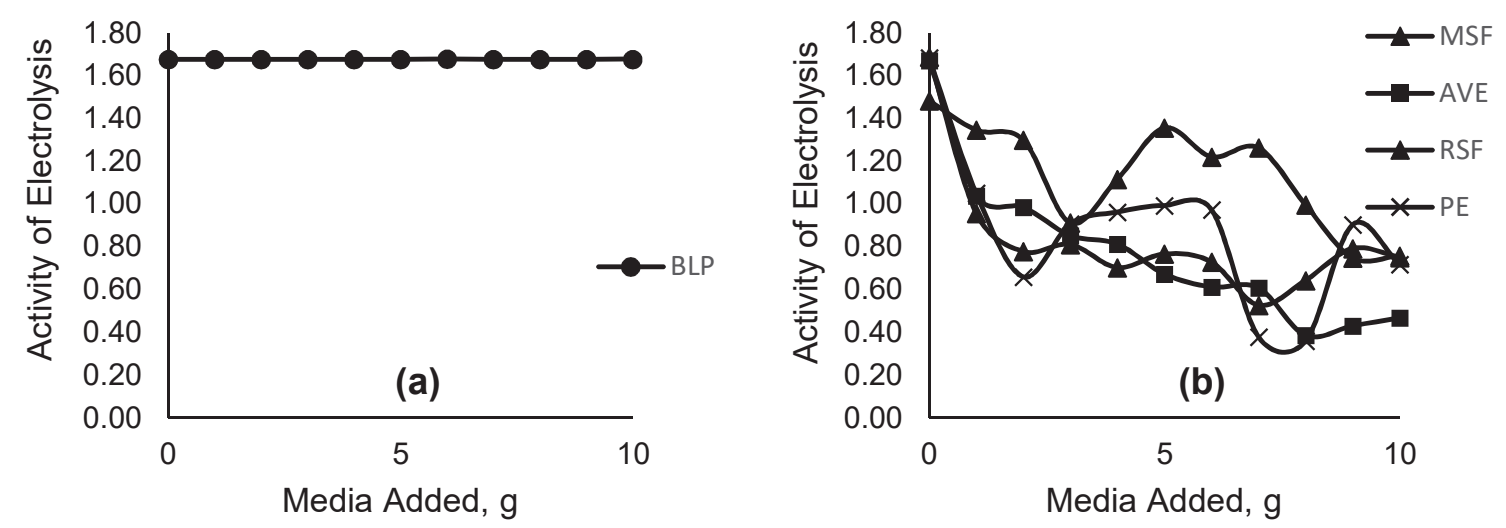

Fig. 6: The activity of electrolysis in various media; (a) unusual trend and (b) usual trend. 
The optimum condition occurred when the electrolysis activity is highest. It is obtained when the production efficiency is high, and the voltage efficiency is low. The higher the cathodic current peak, the higher hydrogen production is, so that the higher the activity of the electrode; and the lower the potential, the lower the voltage efficiency. That is the best condition to decompose water molecules into hydrogen and oxygen gases. Therefore, the optimum condition from this research occurred with the addition of breadfruit leaves powder for which the electrolysis activity was constant around 1.68 .

\section{CONCLUSION}

The activity of stainless steel electrodes in the decomposition of a water molecule into hydrogen and oxygen gases in various media varied greatly. The optimum conditions for water molecule decomposition into hydrogen and oxygen gases were achieved by adding breadfruit leaves powder at every system with similar activity of electrolysis around 1.68 . The addition of various media, regularly, could not improve the electrode activity, but the addition of breadfruit leaves powder could stabilize the electrode activity. The results could give an illustration and initial data to the generalization of hydrogen gas using the electrolysis process in wastewater mainly containing flour media.

\section{ACKNOWLEDGEMENT}

The authors send gratitude to the University for the facilities and support during the research.

\section{REFERENCES}

[1] Fricke, K., Harnisch, F., and Schröder, U., 2008, On the use of cyclic voltammetry for the study of anodic electron transfer in microbial fuel cells, Energy \& Environmental Science, 1(1): 144-147.

[2] Karlberg, G., Jaramillo, T., Skulason, E., Rossmeisl, J., Bligaard, T., and Nørskov, J.K., 2007, Cyclic voltammograms for $\mathrm{H}$ on $\mathrm{Pt}$ (111) and Pt (100) from first principles, Physical Review Letters, 99(12): 126101.

[3] Kissinger, P.T. and Heineman, W.R., 1983, Cyclic voltammetry, Journal of Chemical Education, 60(9): 702.

[4] Van Benschoten, J.J., Lewis, J.Y., Heineman, W.R., Roston, D.A., and Kissinger, P.T., 1983, Cyclic voltammetry experiment, J. Chem. Educ., 60(9): 772.

[5] Rountree, E.S., McCarthy, B.D., Eisenhart, T.T., and Dempsey, J.L., Evaluation of homogeneous electrocatalysts by cyclic voltammetry, ACS Publications, 2014.

[6] Bard, A.J., Faulkner, L.R., Leddy, J., and Zoski, C.G., 1980, Electrochemical methods: fundamentals and applications, wiley New York,

[7] De Nora, O., De Nora, V., and Spaziante, P.M., Electrolysis cells, Google Patents, 1977.

[8] DeNora, O., Electrolysis cell, Google Patents, 1986.

[9] Olivares-Ramirez, J., Campos-Cornelio, M., Godínez, J.U., Borja-Arco, E., and Castellanos, R., 2007, Studies on the hydrogen evolution reaction on different stainless steels, International Journal of Hydrogen Energy, 32(15): 3170-3173. 
[10] Stojić, D.L., Marčeta, M.P., Sovilj, S.P., and Miljanić, Š.S., 2003, Hydrogen generation from water electrolysis - possibilities of energy saving, Journal of Power Sources, 118(12): 315-319.

[11] Zeng, K. and Zhang, D., 2010, Recent progress in alkaline water electrolysis for hydrogen production and applications, Progress in Energy and Combustion Science, 36(3): 307326.

[12] Isana SYL, W.T., Agus Kuncaka and Triyono, 2016, Preparation, Characterization and Application of Stainless Steel/Fe, Co, Ni Electrocatalyst Electrodes, J. Chem. \& Cheml. Sci., 6 (11)1151-1160.

[13] Isana, S., Trisunaryanti, W., and Kuncaka, A., 2012, Studies On The Hydrogen Evolution Reaction On Fe-Co-Ni, IOSR Journal of Applied Chemistry, 6-10.

[14] Louise, I.S.Y., 2014, Stainless steel/Fe-Co-Ni sebagai Elektro Katalis pada Reaksi Evolusi Hidrogen,

[15] Isana S. Y. L., W.T., Agus K., Triyono, Studies on the hydrogen evolution reaction on $\mathrm{Fe}-\mathrm{Co} / \mathrm{s}, \mathrm{Fe}-\mathrm{Ni} / \mathrm{s}$ and $\mathrm{Co}-\mathrm{Ni} / \mathrm{s}$ electrodes, The International Post Graduate Conference on Science and Mathematics 2013, Convention Hall, e-Learning Building, Universiti Pendidikan Sultan Idris, Malaysia, 2013.

[16] Islam, M., 2009, Anomalous Electrodeposition Of Fe-Ni Alloy Coating From Simple And Complex Baths and its Magnetic Property, IIUM Engineering Journal, 10(2): 108-122.

[17] Hairin, A.N., Othman, R., Ani, M.H., and Saputra, H., 2011, High Discharge Rate Electrodeposited Zinc Electrode for Use in Alkaline Microbattery, IIUM Engineering Journal, 12(5): 115-122.

[18] Salim, W.W.A.W., Benoudjit, A., Guthoos, H.F.A., and Arris, F.A., 2017, PEDOT: PSSModified Platinum Microelectrodes for Measurement in Aqueous Media: Effect of Polymer Surface Area on Long-term ANodic Peak Current Stability, IIUM Engineering Journal, 18(2): 11-15.

[19] Isana, S., Variasi Temperatur Dan Waktu Pada Elektrolisis Larutan Garam Dapur Berbagai Merk, Seminar Nasional Kimia, 2009.

[20] Isana, S., Perilaku sel elektrolisis air dengan elektroda stainless steel, Prosiding Seminar Nasional Kimia dan Pendidikan Kimia, Yogyakarta, 2010, pp. 1-9.

[21] Louise, Y.A.A.a.I.S.Y., Reaksi Evolusi Hidrogen Menggunakan Media Tepung Mocaf dengan Elektroda Stainless Steel/Fe-Co-Ni, Jurusan Pendidikan Kimia, Universitas Negeri Yogyakarta, 2016.

[22] Isana S. Y. L., S., Heru Pratomo, Voltamogram siklik stainless steel dalam media tepung ubi jalar (Ipomoea batatas L) (Cyclic voltammogram of stainless steel in Ipomoea batatas L flour), Seminar Nasional Kimia, Jurusan Pendidikan Kimia FMIPA Universitas Negeri Yogyakarta, Yogyakarta, Indonesia, 2016.

[23] Isana, S., Yuanita, D., and Pratomo, H., 2015, Pemecahan Molekul Air dengan Menggunakan Media Tepung Umbi Dahlia (Dahlia Pinnata), Jurnal Sains Dasar, 4(2): 173-178.

[24] Isana, S., Yuanita, D., Sulistyani, A., and Pratomo, H., Voltammogram of stainless steel/Fe-Co-Ni electrode on water electrolysis in base condition with dahlia pinnata tuber starch media, American Institute of Physics Conference Series, 2017.

[25] Isana S. Y. L., H.P.A., Sulistyani, dan Lathifa H., The efficiency of hydrogen production from water electrolysis with bitter melon as a media using stainless steel/Fe-Co-Ni 
electrode, Basic and Applied Sciences Interdisciplinary Conference (BASIC), Universitas Indonesia, Jakarta, Indonesia, 2017.

[26] Isana S. Y. L., S., dan Nur A. R., Breaking of $\mathrm{H} 2 \mathrm{O}$ in mango seed flour medium with stainless steel/Fe-Co-Ni electrode, Basic and Applied Sciences Interdisciplinary Conference (BASIC), Universitas Indonesia, Jakarta, Indonesia, 2017.

[27] Eiamwat, J., Wanlapa, S., Sematong, T., Reungpatthanapong, S., Phanthanapatet, W., Hankhuntod, N., and Kampruengdet, S., 2015, Rambutan (Nephelium lappaceum) seed flour prepared by fat extraction of rambutan seeds with SC-CO2, Isan Journal of Pharmaceutical Sciences, 10138-146.

[28] Okpala, L. and Gibson-Umeh, G., 2013, Physicochemical properties of mango seed flour, Nigerian Food Journal, 31(1): 23-27.

[29] Oladipupo, A.A. and Abiodun, T.G., 2014, Phytochemical analysis and antimicrobial effect of Chrysophillum albidum leave extract on gastrointestinal tract pathogenic bacteria and fungi in human, Journal of Applied Chemistry, 71-5.

[30] Yuwai, K.E., Rao, K.S., Kaluwin, C., Jones, G.P., and Rivett, D.E., 1991, Chemical composition of Momordica charantia L. fruits, J. Agric. Food Chem., 39(10): 1762-1763.

[31] Scala, K.D., Vega-Gálvez, A., Ah-Hen, K., Nuñez-Mancilla, Y., Tabilo-Munizaga, G., Pérez-Won, M., and Giovagnoli, C., 2013, Chemical and physical properties of aloe vera (Aloe barbadensis Miller) gel stored after high hydrostatic pressure processing, Food Science and Technology, 33(1): 52-59. 